\title{
The Drivers of Italy's Investment Slump During the Double Recession
}

\author{
Fabio Busetti ${ }^{1}$. Claire Giordano ${ }^{1}$. \\ Giordano Zevi ${ }^{1}$
}

Received: 21 May 2015 / Accepted: 4 February 2016 / Published online: 22 February 2016 (C) Società Italiana degli Economisti (Italian Economic Association) 2016

\begin{abstract}
This paper examines the causes of the exceptionally marked fall in nonconstruction investment in Italy since 2007. In terms of sector-specific contributions, non-financial private services accounted for most of the decline in the aggregate investment rate, but the reallocation of value added away from industry was also a drag on investment. In concordance with survey findings, an aggregate econometric model of investment indicates that even during the recent double recession the most important driver of capital accumulation was demand conditions. Regarding other determinants of investment it is found that: (i) the user cost of capital had a substantial negative impact in the acute phases of the sovereign debt crisis, but since 2013 its contribution has turned positive; (ii) the constraints imposed by tight credit supply conditions were particularly severe in 2009 and 2012; (iii) uncertainty provided a sizeable drag on investment growth not only during the global financial crisis but also in 2013-2014, being one of the main factors behind the delayed recovery of the Italian economy from the sovereign debt crisis. The significance of these determinants of investment is confirmed also by a disaggregated panel data analysis for thirteen manufacturing branches.
\end{abstract}

Keywords Non-construction investment $\cdot$ Uncertainty $\cdot$ Credit constraints $\cdot$ Sectorial analysis

\footnotetext{
We are grateful to Alberto Locarno, Roberto Sabbatini, Stefano Siviero, Roberta Zizza, Francesco Zollino and two anonymous referees for useful comments on previous versions of this paper. Any error is however our own and the views here reported are those of the Authors and not of the Bank of Italy.
}

$凶$ Claire Giordano

claire.giordano@bancaditalia.it

1 Banca d'Italia, Directorate General for Economics, Statistics and Research, Via Nazionale 91, 00184 Rome, Italy 
JEL Classification E22 - E27

\section{Introduction}

Total real gross fixed investment in Italy fell by around 30 per cent between the outbreak of the global financial crisis, in 2007, and 2014, returning to levels comparable to those of the mid-Nineties. A striking feature of this downturn was its unusual severity and duration, also in an international comparison. The plunge involved all types of expenditure, including construction investment here not discussed.

This paper delves into the causes of Italy's exceptional decline in non-construction expenditure during the double recession occurred between 2007 and 2014, using both statistical and econometric analyses. The economic literature, which we briefly review, has singled out a number of determinants of investment expenditure, including demand conditions, the user cost of capital, uncertainty, credit availability, labour market regulation. We first analyze the most recent survey data on Italy to determine the main obstacles to investment growth as perceived by Italian firms. We next move on to use standard econometric techniques to measure the contribution of each economic factor to the observed investment trends in Italy over the past years.

Our main findings are the following. Among the sectors, the main culprit of Italy's recent investment downturn is the private non-financial service sector, although the allocation of value added away from industry also played a role in the decline. Looking at the economic determinants, according to survey data, demand, financial and uncertainty conditions all contributed to the slump in gross fixed capital formation in Italy. An aggregate econometric model of investment indicates that even during the recent double recession the most important driver of capital accumulation was demand conditions. Moreover, the user cost of capital had a substantial negative impact in the acute phases of the sovereign debt crisis, but since 2013 its contribution has turned positive thanks to the expansionary monetary policy measures enacted. Tight credit supply conditions dampened investment expenditure in particular in 2009 and 2012. Firms' uncertainty provided a sizeable drag on capital accumulation not only during the global financial crisis but also in 2013-14 and it appears as one of the main factors behind the delayed recovery of the Italian economy from the sovereign debt crisis. These macroeconomic results are confirmed by a specific econometric analysis of capital accumulation expenditure in Italy's manufacturing branches.

The structure of the paper is as follows. Section 2 briefly recalls the literature on the determinants of investment decisions. Section 3 provides some descriptive analysis on both the sectorial and economic drivers of the recent developments in non-construction investment in Italy. In particular, it first measures the contribution of each economic sector in explaining the drop in Italy's gross tangible non-construction investment rate. Next, it discusses the findings of the European Commission's Investment Survey for the four largest euro-area countries and exploits the Bank of Italy's most recent business surveys to single out the key factors underlying investment developments in Italy. In Sect. 4 we quantify the role of each economic determinant in explaining the observed downturn in Italy, in particular exploring alternative measures of uncertainty. We first estimate an aggregate investment model for the private sector at a quarterly 
frequency, that includes uncertainty and credit supply conditions. Given its relevance for non-construction investment in Italy, we next analyze a yearly 1986-2012 panel dataset of 13 manufacturing branches, which broadly confirms the results obtained at an aggregate level. Section 5 draws some conclusions. The Appendix provides some further information on non-construction investment developments in an international comparison.

\section{Related Literature on the Determinants of Investment}

The theoretical and empirical literature has singled out several main economic determinants underlying the process of capital accumulation, which we here briefly discuss. First, the "accelerator model" suggests that output and demand fluctuations have a key role in explaining investment behaviour (see e.g. Chirinko 1993). The cost and availability of financial resources, as well as the structure of corporate balance sheets, are also of great relevance in a context in which internal and external funds are not perfect substitutes (see Fazzari et al. 1988 amongst others). ${ }^{1}$ Next, uncertainty has been long recognized as a major factor in investment decisions, in that it may lead to a postponement of investment plans or an increase in the case of more desirable risk-return prospects. Economic theory provides contrasting explanations regarding the sign and relevance of the investment-uncertainty relationship (Leahy and Whited 1996), since it depends on the technological features of firms' production processes and on the structure of the product market. In particular it depends on the degree of reversibility of investment expenses (the more reversible they are, the less relevant is uncertainty; Bernanke 1983), firms' risk aversion and market power (for a risk-neutral competitive firm with constant returns to scale and no irreversibility greater uncertainty increases investment; Abel 1993), the interplay between irreversibility and monopolistic power (in a context of irreversibility, imperfect competition or decreasing returns to scale can lead to a negative effect of uncertainty on investment; Caballero 1991), the degree of flexibility of labour (which can compensate for the irreversibility of investment; Eberly and Van Mieghem 1997). The empirical literature largely converges in pinning down negative effects of uncertainty on capital accumulation. ${ }^{2}$ In particular, on a crosssection of Italian manufacturing firms, Guiso and Parigi (1999) find that firm-specific uncertainty weakens investment, the more when capital expenses are less reversible and the greater the firm's market power. ${ }^{3}$ Bloom et al. (2007), in an influential paper first released in the aftermath of the huge rise in uncertainty following the September 11 events, show that the responsiveness of investment to demand shocks decreases in periods of high uncertainty in a sample of U.K. manufacturing companies.

\footnotetext{
1 Using data on Canada Chirinko and Schaller (1995) find that finance constraints play a large role in investment equations and identify one of their sources as the problems faced by firms in credibly communicating private information to outsiders.

2 See Carruth et al. (2000) for a review of the literature until 2000.

3 By employing panel data for the period 1996-2004, Bontempi et al. (2010) confirm these results and also find that the negative effect of uncertainty on investment plans weakens for firms that can employ a more flexible labour input. Fuss and Vermeulen (2008) show that also for a panel of manufacturing Belgian firms subjective demand uncertainty depresses planned and realized investment, whereas price uncertainty is insignificant.
} 
Among the more recent studies, aimed at analyzing the sharp fall of investment occurred during the Great Recession and the European sovereign debt crisis, Gilchrist et al. (2014) explore the connection between uncertainty and credit shocks and "point to financial distortions as the main mechanism through which fluctuations on uncertainty affects macroeconomic outcomes" (2014, p. 1). Bachmann et al. (2014) employ German IFO Survey microdata and U.S. data from the Philadelphia FED Business Outlook Survey to build survey-based uncertainty indexes and show that the negative impact on investment expenses of rises in uncertainty are stronger in Germany but more persistent in the U.S. (which could reflect stronger capital irreversibility in the former case, a larger impact of financial frictions in the latter). Banerjee et al. (2015) find that uncertainty lowers investment in a quarterly panel of G7 countries while Barkbu et al. (2015) point to a large effect of demand expectations, which is compounded by financial and uncertainty factors in the euro area.

Finally, a strand of the empirical literature focused on the structural features and recent changes in the Italian economy has also suggested the existence of a strong link between labour market regulation and capital accumulation. In particular, according to Saltari and Travaglini (2009) and Ciccarone and Saltari (2015), increased labour market flexibility since the mid-Nineties favoured the adoption of labour-intensive production techniques to the detriment of investment, therefore especially weakening the accumulation of the more innovative capital components.

Ultimately at the empirical level it appears important to assess the relevance and the relative weight of all mentioned factors in driving investment expenditure. This paper attempts to provide an answer to this question for the Italian economy, focusing on the double recessionary period 2007-2014.

\section{Some Descriptive Statistical Analyses of Italy's Investment Downturn: Sector-Specific Developments and Evidence from Surveys}

A comparison with past crises proves that the recent double recession in Italy has been exceptionally long and intense, both for gross domestic product (GDP), which cumulatively fell by nearly 10 per cent, and for gross fixed capital formation (GFCF; Table 1). ${ }^{4}$ While GDP declined more strongly in 2008-2009 than in 2011-2014, the downturn in investment was more severe in the latter recession. The drop in GFCF in 2007-2014 was broad-based across investment goods, with all types of expenditure at present below their pre-crisis level. Moreover, it was particularly severe relative to the declines observed in the other four largest euro-area countries. ${ }^{5}$

Focusing on the share of GFCF in GDP, between the inception of the European Monetary Union and the outbreak of the global financial crisis in 2007 Italy's nonconstruction investment rate was not at all dismal in an international perspective: it was indeed comparable to Germany and France's ratios (nearly 10 per cent) and in

\footnotetext{
4 The apparent co-movement between output and non-construction investment in the post-2007 downturns is however broadly similar to that observed during the historical recessions (i.e. with GFCF contracting about three to four times more than GDP), with the exception of the 1992-1993 crisis, when the decline in overall economic activity was exceptionally contained in relative terms.

5 See Appendix for details.
} 
Table 1 The decline in GDP and in investment during Italy's recent recessions

\begin{tabular}{|c|c|c|c|c|c|c|}
\hline & \multirow[t]{2}{*}{ GDP } & \multicolumn{2}{|l|}{ GFCF } & \multirow[t]{2}{*}{ GDP } & \multicolumn{2}{|l|}{ GFCF } \\
\hline & & Non-construction & Total & & Non-construction & Total \\
\hline & \multicolumn{3}{|c|}{ 1973-1976 (1) } & \multicolumn{3}{|c|}{ 1992-1993 } \\
\hline $\begin{array}{l}\text { Number of } \\
\text { consecutive } \\
\text { quarters of } \\
\text { decline/increase }\end{array}$ & 3 & 6 & 10 & 6 & 6 & 8 \\
\hline \multirow{2}{*}{$\begin{array}{l}\text { Cumulative } \\
\text { percentage change }\end{array}$} & -3.8 & -15.1 & -8.5 & -1.5 & -20.4 & -15.2 \\
\hline & \multicolumn{3}{|c|}{ 2007-2009 (2) } & \multicolumn{3}{|c|}{ 2010-2014 (3) } \\
\hline $\begin{array}{l}\text { Number of } \\
\text { consecutive } \\
\text { quarters of } \\
\text { decline/increase }\end{array}$ & 6 & 7 & 8 & 14 & 13 & 15 \\
\hline \multirow{2}{*}{$\begin{array}{l}\text { Cumulative } \\
\text { percentage change }\end{array}$} & -7.0 & -20.6 & -14.2 & -5.5 & -22.8 & -19.7 \\
\hline & \multicolumn{3}{|c|}{ 2009-2010 (4) } & \multicolumn{3}{|c|}{ 2007-2014 (5) } \\
\hline $\begin{array}{l}\text { Number of } \\
\text { consecutive } \\
\text { quarters of } \\
\text { decline/increase }\end{array}$ & 7 & 8 & 3 & $6+14$ & $7+13$ & $8+15$ \\
\hline $\begin{array}{l}\text { Cumulative } \\
\text { percentage change }\end{array}$ & 2.8 & 11.2 & 1.2 & -9.6 & -31.8 & -30.3 \\
\hline
\end{tabular}

Source: Authors' calculations on Istat data

Notes: We exclude investment in intellectual property products since the national account series prior to 1995 do not include Research and Development expenditure and are therefore not comparable. (1) This period includes two quarters of slightly positive growth; (2) The period begins in 2007Q3 for non-construction GFCF and 2008Q1 for the other variables. It includes one quarter of positive growth for total GFCF; (3) The period includes one quarter of slightly positive growth for GDP and total GFCF and three quarters for non-construction GFCF; (4) The period includes one quarter of slightly decreasing total GFCF; (5) Overall decline since 2007-2008

turn about one percentage point higher than Spain's investment rates (Fig. 1; Table 2). However, in Italy the decline thereafter was the most long-lasting and pronounced across the four countries, leading to the lowest investment rate in 2014, at 8.3 per cent. In 2015 Italy was the only large euro-area country recording an "investment gap" relative to its 2000-2007 average, although in all four countries, with the exception of France, the investment rate was lower than the 2007-2008 peak.

\subsection{Sectorial Drivers of Italy's Investment Downturn}

A sectorial analysis helps shed light on the drivers of Italy's sharp investment decline in recent years. Changes in the total-economy investment rate stem from changes in investment intensity in each industry ("within effect") and varying shares of each sector in total output ("between effect"). Via shift-share analysis, it is therefore possible to ascertain to what extent aggregate investment rates reflect the investment behaviour in individual sectors and the changing sectorial composition of the economy. By defining 


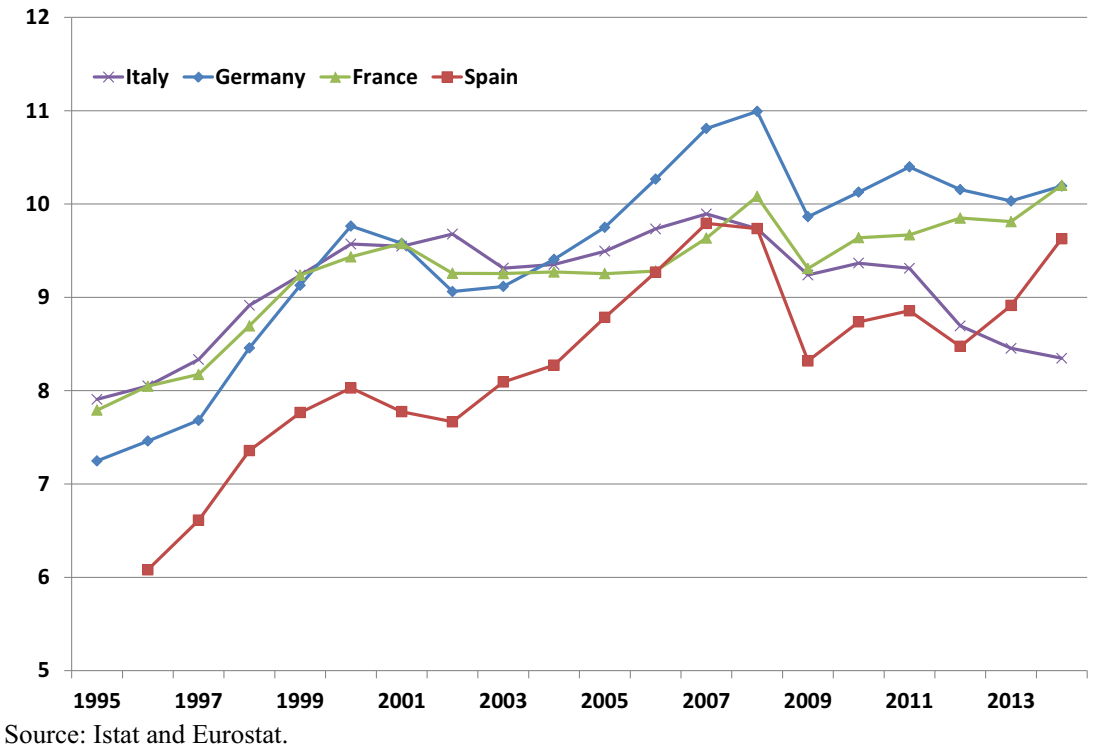

Fig. 1 Gross fixed non-construction investment rates in the four largest euro-area countries (percentage shares in GDP at market prices, computed on chain-linked volumes)

Table 2 The current non-construction "investment gap" in the four largest euro-area countries (percentage shares, when otherwise not indicated, computed on chain-linked volumes)

\begin{tabular}{llllll}
\hline & $\begin{array}{l}\text { A } \\
\text { Medium-term } \\
\text { average (1) }\end{array}$ & $\begin{array}{l}\text { B } \\
\text { Pre-crisis } \\
\text { peak (2) }\end{array}$ & $\begin{array}{l}\text { C } \\
2014 \\
\text { investment } \\
\text { rate }\end{array}$ & $\begin{array}{l}\text { D } \\
\text { Investment gap rel- } \\
\text { ative to medium- } \\
\text { term average (3) }\end{array}$ & $\begin{array}{l}\text { E } \\
\text { Investment gap rel- } \\
\text { ative to pre-crisis } \\
\text { peak (4) }\end{array}$ \\
\hline Italy & 9.6 & 9.9 & 8.3 & -1.3 & -1.6 \\
Germany & 9.7 & 11.0 & 10.2 & 0.5 & -0.8 \\
France & 9.4 & 10.1 & 10.2 & 0.8 & 0.1 \\
Spain & 8.5 & 9.8 & 9.6 & 1.1 & -0.2 \\
\hline
\end{tabular}

Source: Authors' calculations on Istat and Eurostat data

Notes: (1) 2000-2007 annual average; (2) 2007 for Italy and Spain, 2008 for Germany and France; (3) D= $\mathrm{C}-\mathrm{A}$. In percentage points; (4) $\mathrm{E}=\mathrm{C}-\mathrm{B}$. In percentage points

$X \equiv \frac{I}{Y}$, where $\mathrm{I}$ is nominal GFC and $\mathrm{Y}$ is nominal value added, the investment rate can be expressed as

$$
X=\sum_{s=1}^{n} X_{s} \frac{Y_{s}}{Y}
$$

where $s$ is one of the $n$ sectors of the economy.

Taking time differentials (where ${ }^{\wedge}$ indicates differentials),

$$
\widehat{X}=\sum_{s=1}^{n} \widehat{X}_{s} \frac{Y_{s}}{Y}+\sum_{s=1}^{n} X_{s} \frac{\widehat{Y}_{s}}{Y}
$$


and dividing both terms by $\mathrm{X}$, with simple algebraic manipulations we obtain the following decomposition:

$$
\frac{\hat{X}}{X}=\sum_{s=1}^{n} \frac{\widehat{X}_{s}}{X_{s}} \frac{I_{s}}{I}+\sum_{i=1}^{n} \frac{I_{s}}{I}\left(\frac{\hat{Y}_{s}}{Y_{s}}-\frac{\hat{Y}}{Y}\right)
$$

The first term on the right-hand side of the equation is the "within effect" and the second term is the "between effect".

We break the total economy down into six sectors: (i) agriculture, forestry and fishing; (ii) industry (except utilities); (iii) private regulated sector (utilities; transport and communication); (iv) finance, insurance and real estate (FIRE); (v) private unregulated services; (vi) public sector (public administration, health and education). We here consider only tangible non-construction investment, owing to its much less favourable dynamics than those reported for intangible GFCF. ${ }^{6}$

Since the mid-Nineties the sectorial breakdown of gross fixed tangible nonconstruction capital formation has been stable in Italy (Table 3, figures in brackets). Industry is the key sector in tangible non-construction investment, undertaking on average around 39 per cent of total expenditure, which is also a large share in an international comparison (Busetti et al. 2015). Conversely, the weight of private (regulated and unregulated) services is relatively low, as is public investment spending, owing to fiscal consolidation that began in the mid-Nineties.

Figure 2 presents the shift-share decomposition of the change in aggregate tangible non-construction investment rates in Italy for three sub-periods (1996-1999; 20002007; 2008-2012), also reported in the last column of Table $3 .^{7}$ The sum of the contributions of each sector is the total "within effect". 8

In 1995-2012 private services were the main driver of the total economy tangible non-construction investment rate dynamics in Italy, with a larger contribution coming from the unregulated vis-à-vis the regulated sector as of the 2000s. Industry too was an important positive contributor until 2007, explaining on its own nearly one third of the total "within effect". Whereas in the years prior to the global financial crisis the aggregate "within effect" was positive (in particular, reflecting positive investment rate changes in all sectors before the inception of the European Monetary Union), in the recent recessionary period until 2012 sectorial investment rates declined across the board. Non-financial private services were the main driver of the recent aggregate downturn: in particular, this sector explains about two-thirds (i.e. over 2 percentage points) of the total-economy investment rate decline, against a negative contribution of industry of less than 0.5 percentage points, notwithstanding its roughly equivalent weight. The "between effect"- - which reflects the tendency to a reallocation of value

\footnotetext{
6 The analysis for intangible expenditure may be found in Busetti et al. (2015).

7 The shift-share analysis of this section is conducted on current price series, owing to non-additivity of constant price series. Annual average changes are taken for each sub-period; similar results are obtained when considering cumulative changes over each sub-period. See Busetti et al. (2015) for a similar analysis conducted also for France, Germany and Spain.

${ }^{8}$ Rounding up leads to small discrepancies between the aggregate investment rate and the sum of the "within" and "between" effects.
} 


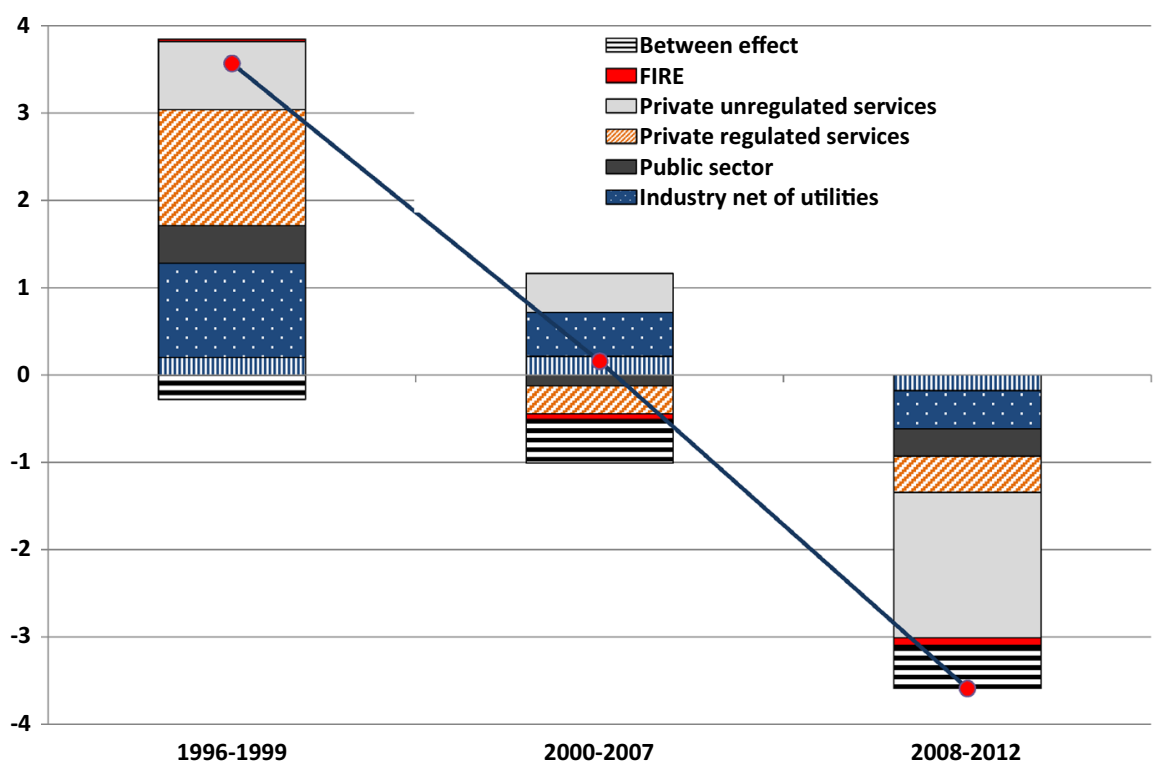

Source: Authors' calculations on Istat data.

Fig. 2 The decomposition of changes in tangible non-construction investment rates in Italy (current prices; annual average changes)

added away from industry, a high-investment intensity sector, to the less capital intensive private services sector-also contributed negatively to overall investment rate developments in the most recent years, as in the previous sub-periods. ${ }^{9}$

This analysis suggests that for the coming years the inversion of the declining trend in the total economy tangible non-construction investment rate is crucially related to the materialization of a significant recovery in private non-financial service expenditure.

\subsection{Economic Drivers of Italy's Investment Decline According to Survey Data}

The European Commission (EC) Investment Survey, taken bi-annually in spring and autumn, allows us to analyze firms' perceptions on the economic determinants of the recent decline in Italy's manufacturing investment and to set them in an international perspective. ${ }^{10}$ According to this survey, insufficient demand prospects and a low capacity utilization rate were significant factors constraining investment in manufacturing in Italy during the double recession, in addition to policy uncertainty (included

\footnotetext{
9 Value added in industry net of utilities consistently grew less than the total economy since the midNineties. In particular, in 2007-2012 whereas the total economy output increased on average by 0.2 per cent each year, industrial value added actually declined by an annual rate of 2.4 per cent (figures here not shown).

10 A comparison between the declarations of surveyed manufacturing firms on their realized investment and comparable national account data shows that the EC Investment Survey is particularly informative in the case of France and Germany, less telling for Italy_-for which the Bank of Italy's yearly Survey of Industrial and Service Firms (Invind) conducted in spring is more indicative - and not very useful for Spain. See Busetti et al. (2015) for further details.
} 


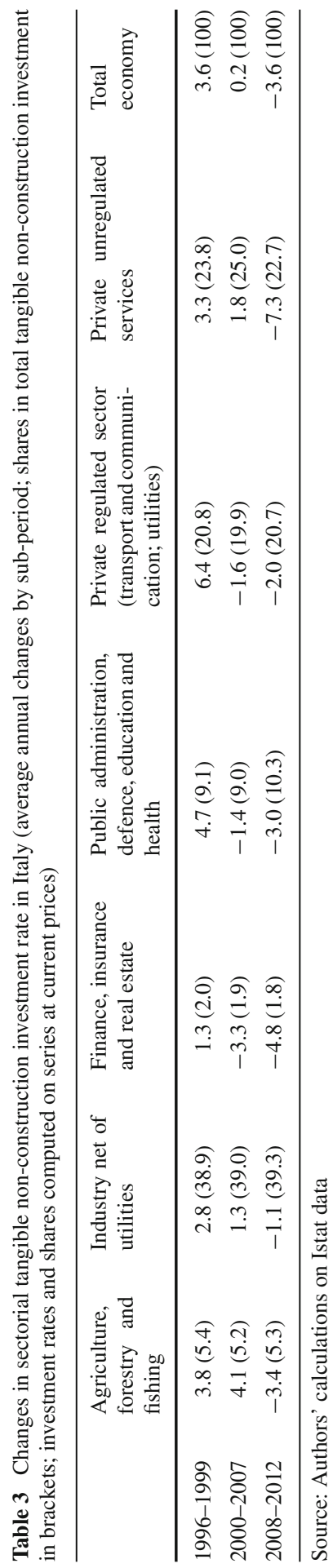



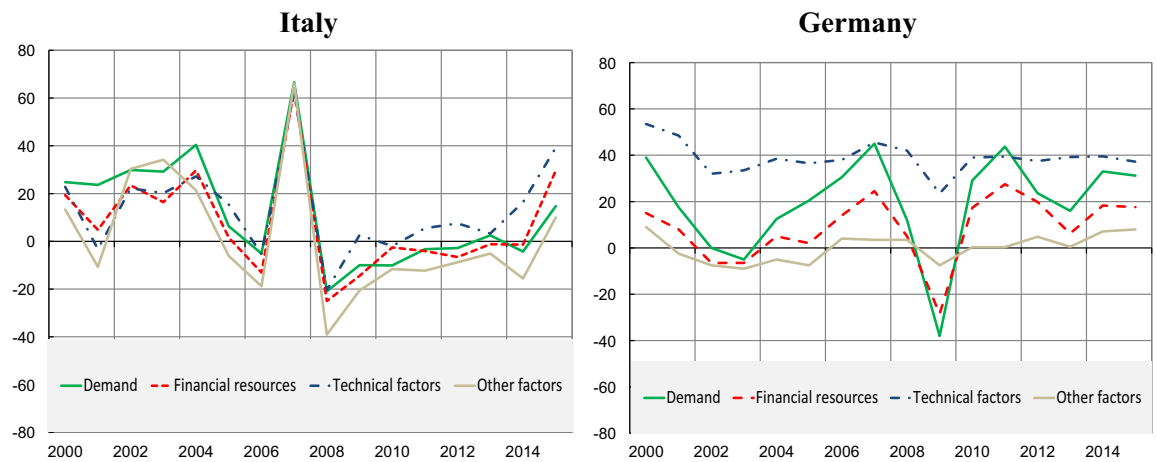

France
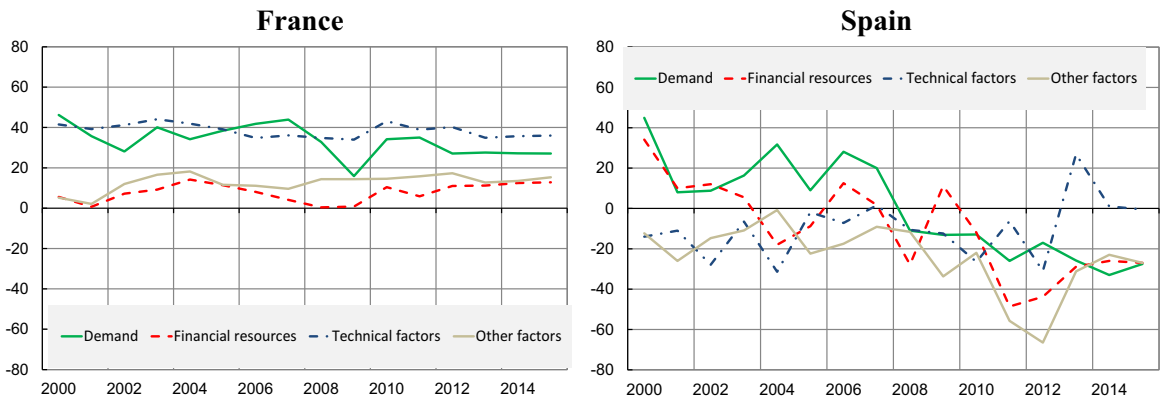

Source: European Commission.

Note: (1) "Demand" covers the capacity utilization rate and sales prospects; "financial resources" refers to the availability and cost of resources for investment, and the return on investment; "technical factors" include technological developments, the availability of labour, the labour-force's attitude towards newtechnologies and the technical conditions to be met to obtain investment permits; "other factors" include, for example, public policies, notably with regard to taxation, and whether or not production can be transferred abroad

Fig. 3 The drivers of manufacturing firms' investment according to the EC Investment Survey (1) (balances; percentage points)

in 'other factors'; Fig. 3). The drag on investment spending stemming from financial constraints was particularly severe in 2009 and in 2012 but subsequently waned, similarly to all other obstacles to investment. Technological factors have actually returned to boosting GFCF in Italy since 2010.

The EC Investment Survey does not explicitly include economic uncertainty among the determinants of investment. Limited to Italy, the Bank of Italy's survey Invind, taken in spring, allows gauging the effects of a measure of this type of uncertainty on investment expenses at firm level. ${ }^{11}$ We classify the firms for which the uncertainty (on expected turnover growth) is above the 75 percentile as "high uncertainty" units, those for which it is below the 25 percentile as "low uncertainty", and the remaining units as "average uncertainty". The left panel of Fig. 4 shows the difference, according to these three groups of firms, between the share of firms that expect higher investment at year $\mathrm{T}$ for year $\mathrm{T}+1$ and those that expect less investment; the black line indicates

\footnotetext{
11 Specifically, firms are requested the maximum and minimum expected growth rate in their turnover for the next year.
} 
the change in investment recorded by national accounts, shifted backward by one year in the left panel. For most years in the period under study the plans previously formulated by high-uncertainty firms were especially pessimistic in comparison to the other groups. In the right panel of Fig. 4 the percentages of firms increasing or decreasing realized investment in year $\mathrm{T}$ are separated into groups defined by ex ante uncertainty (measured in year T-1). Again for much of the 2007-2013 period the most uncertain firms tend to confirm even ex post their lower investment.

\section{Econometric Analyses of Non-Construction Investment Dynamics in Italy}

We now move on to substantiate the described survey evidence for Italy by means of econometric analyses. Special emphasis will be placed on evaluating the impact of uncertainty, which could potentially strongly and negatively affect firms' investment decisions during bad economic times. First, we provide aggregate evidence for private sector non-construction investment using an econometric relationship that follows the modeling approach in the Bank of Italy Quarterly Model (BIQM), augmented to take into account uncertainty and credit supply conditions. Using these estimates we present a decomposition of the fall in investment occurred during the double recessionary period 2007-2014 in terms of the contributions of various determinants. Next we provide panel estimates of the effects of uncertainty and liquidity conditions for 13 manufacturing branches. This evidence broadly confirms and corroborates the previous results based on aggregate data. Focusing on manufacturing is indeed particularly relevant for Italy, given the high non-construction investment rate of this sector in an international perspective, as seen in Sect. 3.1. In both the aggregate and disaggregate approaches, uncertainty is proxied with survey measures of the dispersion of agents' expectations on their own demand conditions and/or on the general economic environment.

\subsection{Aggregate Estimates for Private Sector Non-Construction Investment (Quarterly Data)}

We first assess the impact of the various determinants of the private sector nonconstruction investment using an econometric relationship that follows the modeling approach of the BIQM. In particular, the investment equation is obtained within a standard neoclassical model where firms derive investment and labour demand by a cost minimization problem, given factor prices and the desired level of additional production capacity. Assuming a Cobb-Douglas production function and the non-malleability of capital, it is known that desired investment as a share of expected demand is equal to the optimal capital/output ratio $\mathrm{K}^{*}$, which in turn is a function of factor prices. ${ }^{12}$

The empirical counterpart is a dynamic model of investment with long-run homogeneity restrictions between investment and the capital/output ratio and investment and output; expectations and adjustment costs are taken into account by including several

$\overline{12}$ See Busetti et al. (2005) for further details on the BIQM specification. 


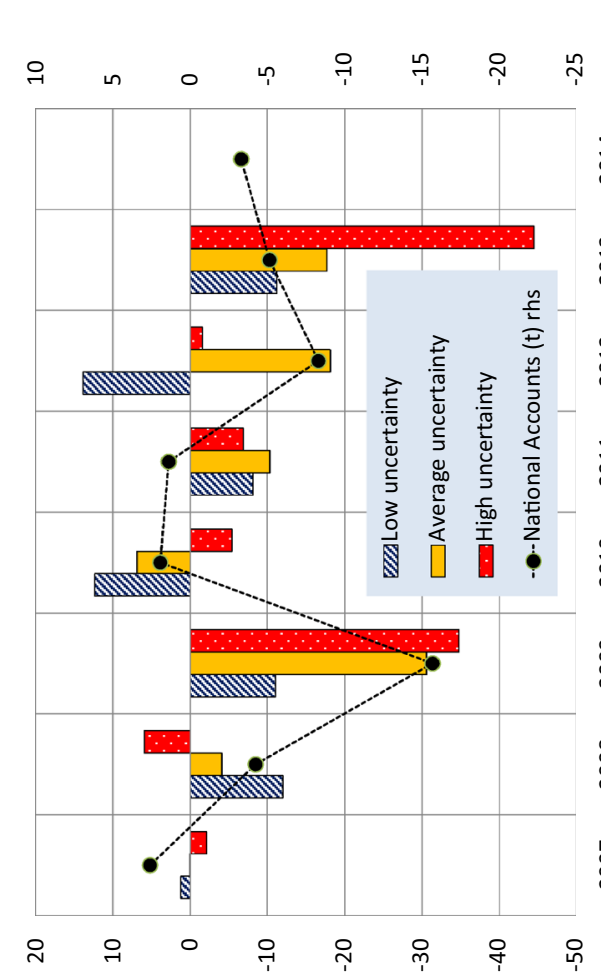

$\stackrel{\text { กิ }}{\stackrel{\Xi}{\Xi}}$

ते

恋

$\stackrel{m}{\sim}$

苛

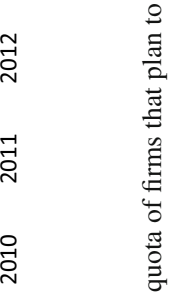

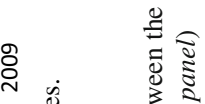

造

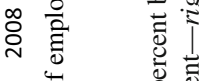

पे एँ

仓े

政

우 우

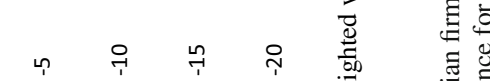

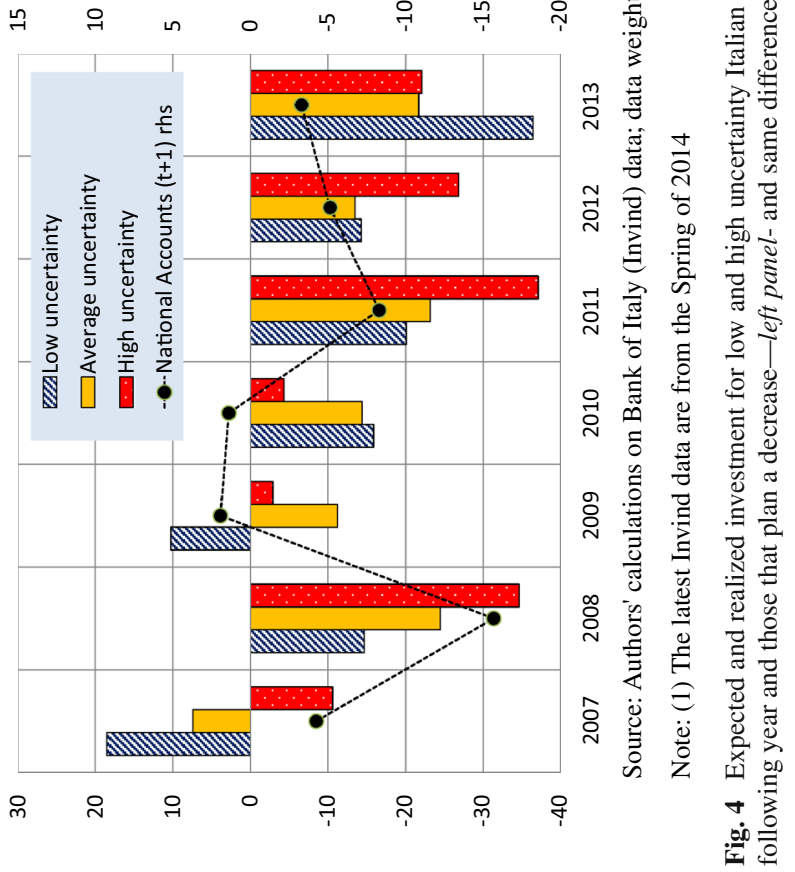


lags of the private sector value added and the capital/output ratio. The estimated model is thus specified as:

$$
\begin{aligned}
\Delta i_{t}= & \beta_{0}+\beta_{1}\left(i_{t-1}-\left(k_{t-1}^{*}\left(u c_{t-1}\right)+y_{t-1}\right)\right)+\sum_{j=1}^{p} \beta_{2, j} \Delta y_{t-j} \\
& +\sum_{j=1}^{q} \beta_{3, j} \Delta k_{t-j}^{*}\left(u c_{t-j}\right)+\gamma^{\prime} z_{t},
\end{aligned}
$$

where $i_{t}, y_{t}, k_{t}^{*}\left(u c_{t}\right)$ are (the logarithm of) the investment expenditure, the private sector value added and the optimal capital/output ratio, respectively, the latter being a known function of the user cost of capital $u c_{t} ; \Delta$ is the first difference operator. ${ }^{13}$

Compared with the standard neoclassical model, the equation includes three additional determinants:

$$
z_{t}=\left(\text { confid }_{t}, \text { uncert }_{t}, \text { credit }_{t}\right)^{\prime},
$$

that are aimed at capturing the effects of: (i) entrepreneurs' level of confidence on the general and own economic outlook, (ii) firms' uncertainty proxied by a measure of dispersion of their 'sentiments' (second moments), (iii) credit conditions.

In more detail, the level of confidence is measured by the average sentiment indicator for manufacturing firms published by Istat. ${ }^{14}$ For uncertainty several proxies are considered. From the Istat survey we derive a dispersion measure of replies regarding expectations for (1) orders, (2) production, and (3) general economic situation. These measures of uncertainty, defined as in Fuss and Vermeulen (2008) and Bachmann et al. (2014), ${ }^{15}$ are forward-looking and time-varying. ${ }^{16}$ In addition we look at (4) the dispersion (in terms of standard deviation) among the forecasts of Italian GDP provided by the analysts surveyed by Consensus Economics. These four different measures are shown in Fig. 5 for the period 1986Q1-2014Q4, together with (5) an 'average

13 Standard unit roots and stationarity tests provide statistical evidence for a unit root in the series of investment, value added and capital/output ratio. The equation for investment is therefore specified in first differences, with an error correction term, ect $\equiv i_{t-1}-\left(k_{t-1}^{*}\left(u c_{t-1}\right)+y_{t-1}\right)$, to account for deviations from long-run developments consistent with economic theory; according to standard tests the error correction term is a stationary process.

14 This variable can be interpreted as a way of capturing the more forward-looking component of expected demand.

15 In particular, the dispersion measure is computed as uncert = $\sqrt{\operatorname{frac}_{t}^{+}+\mathrm{frac}_{t}^{-}-\left(\mathrm{frac}_{t}^{+}-\mathrm{frac}_{t}^{-}\right)^{2}}$, where $\mathrm{frac}_{t}^{+}$and $\mathrm{frac}_{t}^{-}$are the fractions of firms in the cross section with "increase" and "decrease" responses at time t. This measure is the cross-sectional standard deviation of survey responses when the "increase" response is coded as 1 , the neutral response as 0 and the "decrease" response as -1 . This measure approximates the variance of demand shock under a set of assumptions, as shown in Fuss and Vermeulen (2008), and statistically it is similar to Theil (1952) disconformity index.

16 A possible limitation of these measures is that the questions they are based on refer to a short time horizon (3 months). Since uncertainty on longer horizons is likely to be positively correlated with uncertainty on shorter time spans, the employed measure should capture a relevant part of firms' demand uncertainty. 


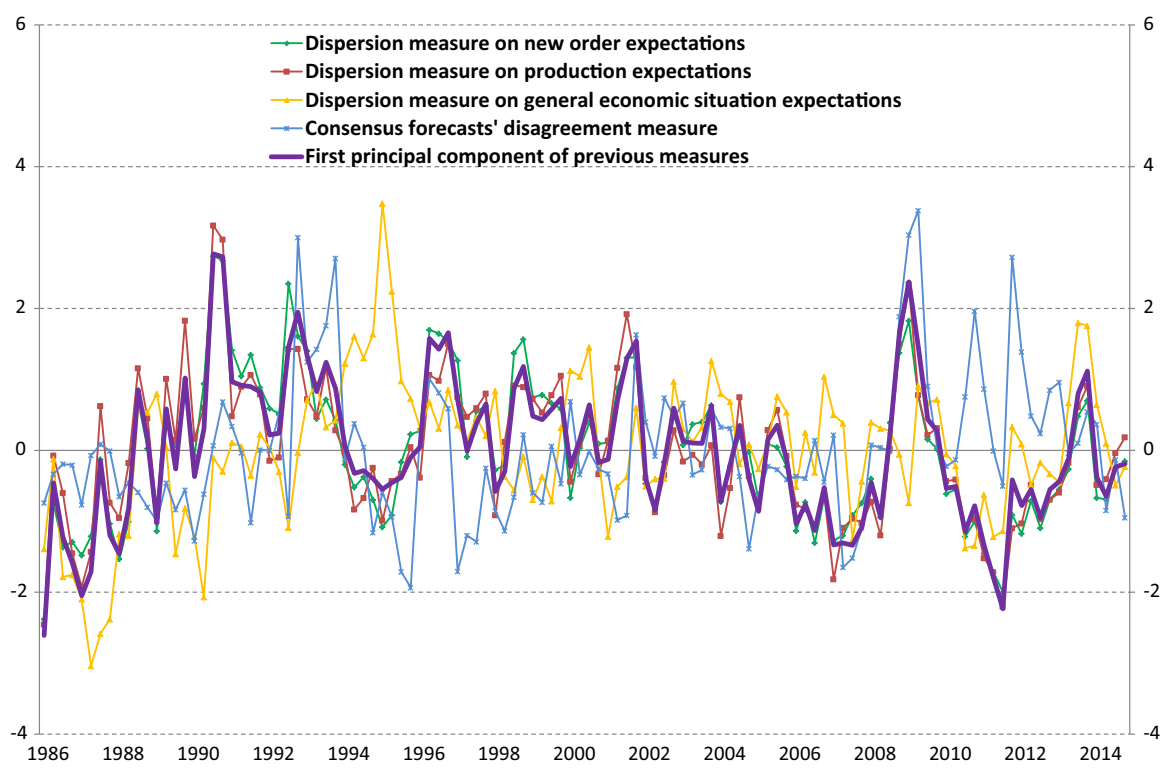

Source: Authors' calculations on Istat and Consensus Economics data.

Note: (1) The measures have been standardized

Fig. 5 Alternative measures of uncertainty (1)

measure' obtained by taking the first principal component (PC) of (1), (2), (3) and (4). Finally, credit frictions are captured by the synthetic indicator of credit supply conditions obtained from the Italian Bank Lending Survey. ${ }^{17}$

The model has been estimated by OLS with quarterly data over the period 19862013. Table 4 reports the regression results in terms of coefficients (with t-statistics provided in brackets) and main diagnostics. ${ }^{18}$ The columns differ according to the proxy used for uncertainty displayed in Fig. 5; the principal component is in the last column. The short-run coefficients for output and capital/output ratios reported are the sum of the parameters of the respective distributed lags in the estimated equation. Using one-sided Gaussian critical values, nearly all coefficients are statistically significant at least at the 10 per cent level. Clearly, there is some degree of collinearity among the confidence, uncertainty and credit restrictions indicators, which turn out to inflate somewhat the coefficients' standard errors. The regression results and the properties of the model happen to be very similar for all measures of uncertainty considered.

The properties of the estimated model are better summarized in Fig. 6, which reports the response of investment (with respect to a baseline level) to shocks to its

\footnotetext{
17 We use the index of supply tightening for firms, that is a weighted average of the values assigned to the qualitative answers obtained from the banks involved in the survey as follows: $1=$ tightened considerably, $0.5=$ tightened somewhat, $0=$ basically unchanged, $-0.5=$ eased somewhat, $-1=$ eased considerably. See http://www.bancaditalia.it/statistiche/tematiche/moneta-intermediari-finanza/intermediari-finanziari/ indagine-credito-bancario/index.html for details.

18 The Chow predictive test measures the adequacy of the model, estimated with data up to 2013, to predict the observed dynamics of investment during 2014.
} 


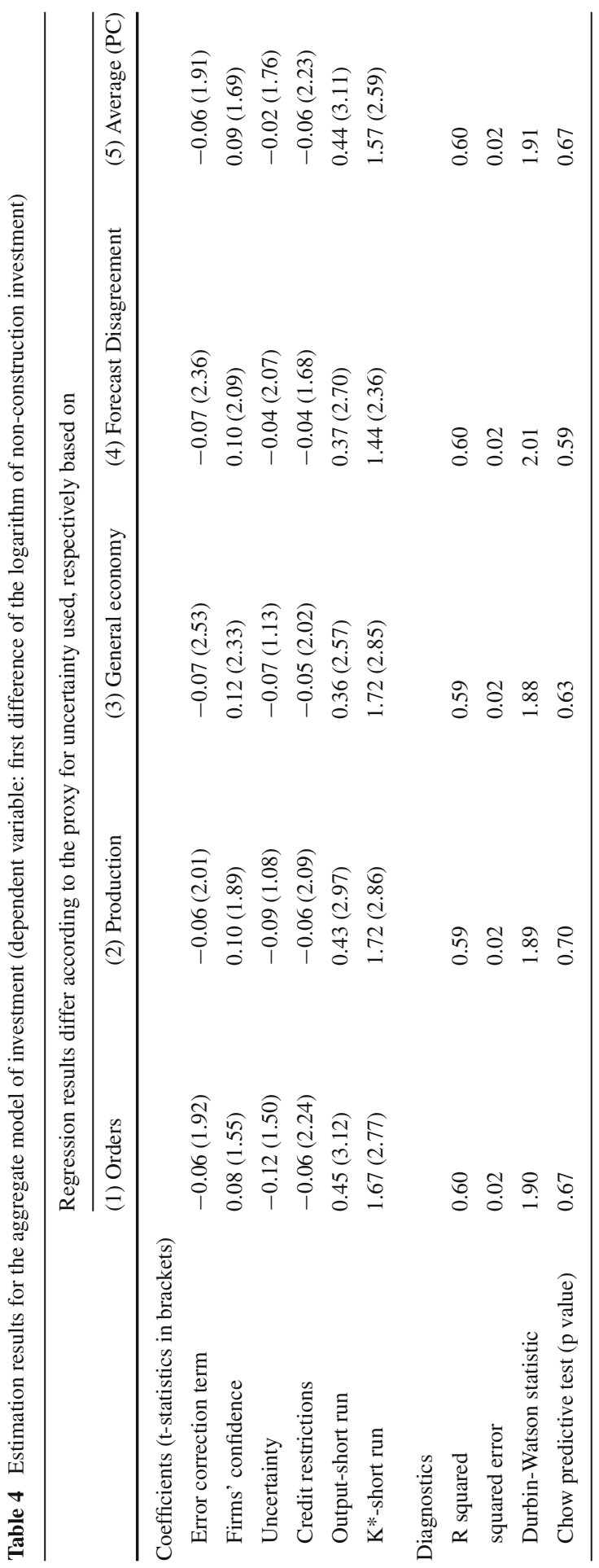



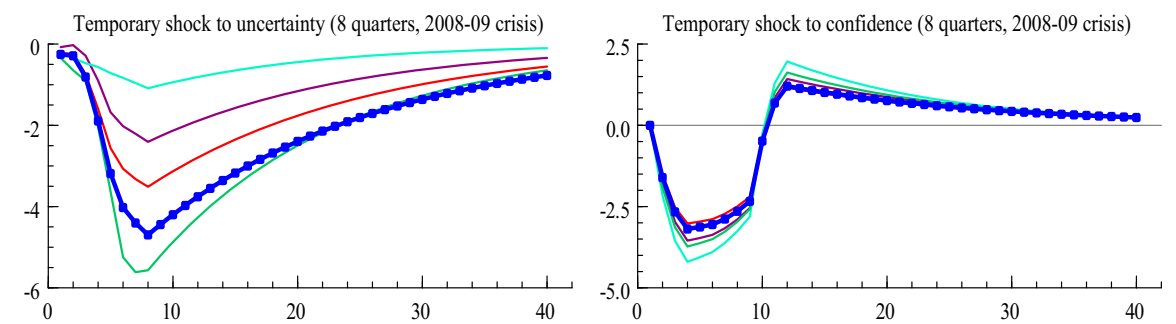

Temporary shock to credit restrictions (8 quarters, 2008-09 crisis)
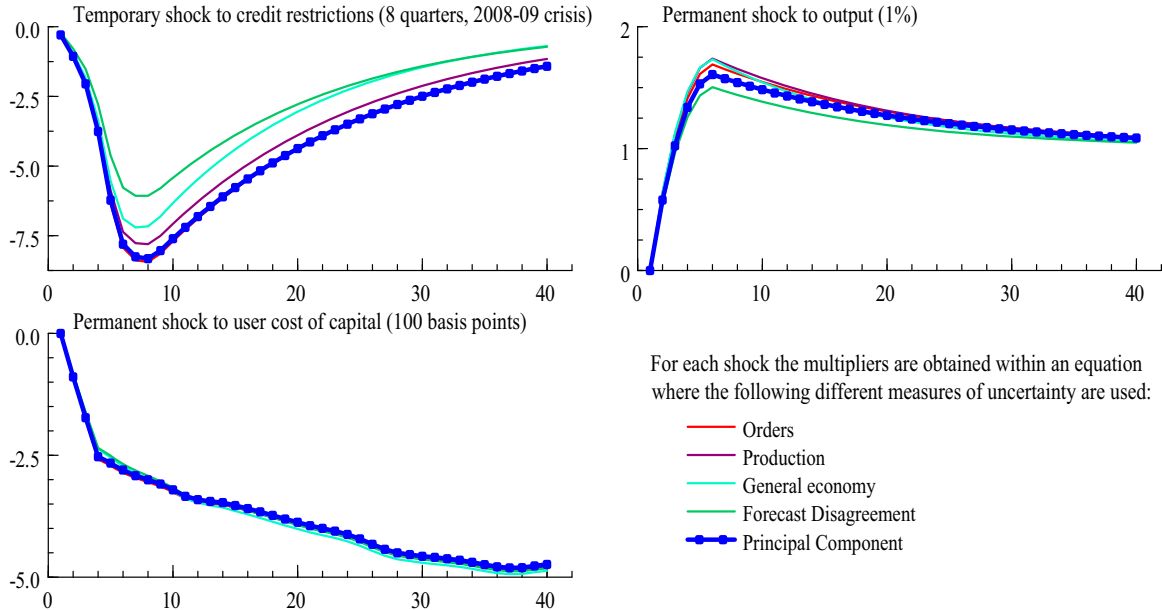

For each shock the multipliers are obtained within an equation where the following different measures of uncertainty are used:

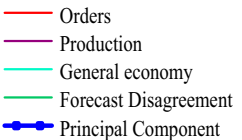

Fig. 6 Dynamic multipliers of the investment equation with respect to shocks to uncertainty, confidence, credit supply conditions, output, user cost of capital

determinants after $1,2, \ldots, 40$ quarters, the so-called "dynamic multipliers". Specifically, we consider: (1) a temporary (2 years) shock to uncertainty, calibrated with what was observed at the time of the Great Recession (we apply for 8 quarters the difference between the average values in the uncertainty indicator between 2008-2009 and 2006-2007); (2) a temporary (2 years) shock to confidence, similarly calibrated; (3) a temporary (2 years) shock to credit supply conditions, similarly calibrated; (4) a permanent increase by 1 per cent in output; (5) a permanent increase of 100 basis points in the real user cost of capital.

The effects of uncertainty shocks to investment are provided in the top left panel. A worsening of uncertainty of a similar magnitude as that observed during the 20082009 recession curbs investment sizably, cumulatively by about 5 per cent after two years according to the first principal component of the four elementary indicators.

Following a temporary shock to the level of firms' confidence, calibrated looking at the average deterioration recorded during the Great Recession, the maximum impact on investment falls between 3 and 4 per cent, but vanishes rapidly as the shock disappears. ${ }^{19}$

19 The shock given to uncertainty is gradual and mostly absorbed after 8 quarters, as seen in the actual data. By contrast the negative shock given to confidence is still large after 8 quarters: this explains the sharp rebound of the dynamic multiplier in the figure when the shock is removed. 


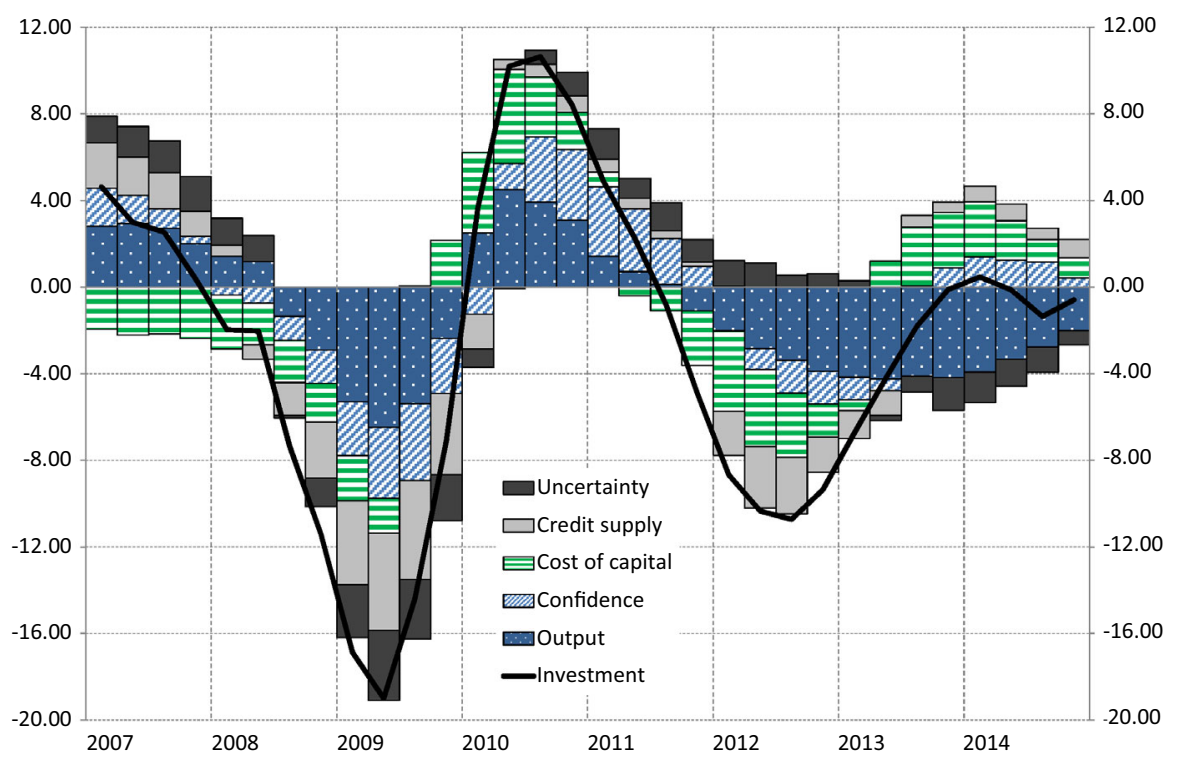

Fig. 7 Factors driving the dynamics of the private sector's non-construction investment since the Great Recession (percentage values)

Credit restrictions of a magnitude similar to what was on average observed in 2008-2009 exert a sizable negative impact on investment, ranging between 6 and 8 per cent after two years. This result appears broadly in line with the estimates reported in Panetta and Signoretti (2010) and Caivano et al. (2010), where several different ways of identifying the effects of the credit supply restrictions of 2008-2009 were considered. ${ }^{20}$

As regards the effects of shocks in output, the 'accelerator' is found to reach a peak in the second year when the elasticity of investment to output is between 1.5 and 1.8; the elasticity then gradually returns to 1 following the long term constraint imposed, and tested, in the model.

Finally, a permanent rise of 100 basis points in the real user cost of capital has a gradual and prolonged negative impact on investment, peaking at about -5 per cent after 10 years ( -4 after 5 years). It is noteworthy that the multipliers with respect to output and the cost of capital are similar (albeit somewhat smaller) to those that were estimated using data before the crisis, as reported in Busetti et al. (2005).

The estimated model of investment can shed light on the factors behind the large decline in capital accumulation observed during the double recession. Figure 7 shows the contributions of each of the determinants included in the model to the year-onyear growth rate of the private-sector non-residential investment. ${ }^{21}$ In most periods the

20 Those papers reported a negative impact on GDP in a range between 0.5 and 1.5 per cent, which seems consistent with our figures for non-construction private investment (that in 2008-2009 accounted by about one tenth of GDP).

21 The quarterly series of private-sector non-construction investment has been obtained by a standard temporal disaggregation methodology that uses the quarterly series available for the whole economy. For 2013 and 2014 the data for non-construction investment for the public sector (from which private sector's 
main driver is the demand component (sum of the output and confidence contributions). The real user cost of capital provided a large negative impact during the most acute phases of the sovereign debt crises, but contributed positively since 2013 (overall by nearly 4 percentage points), mainly reflecting the effects of the expansionary monetary policy measures adopted by the European Central Bank. The constraints to capital accumulation imposed by tight credit supply conditions accounted about one third of the fall in investment occurred during the periods 2008-2009 and 2012-2013. Finally, uncertainty provided a sizeable negative impact not only during the Great Recession but also since mid-2013, and stands out as one of the factors explaining the delayed recovery of the Italian economy.

The econometric decomposition in Fig. 7 is consistent with the qualitative results coming from the surveys and described in Sect. 3.2. An analysis by the IMF also provides a broadly similar assessment (International Monetary Fund 2015). The results presented here are also consistent with the counterfactual exercise of Busetti and Cova (2013) where simulations of the BIQM were used to identify the contributions of the main factors related to the sovereign debt crisis.

\subsection{Annual Panel Estimates on Manufacturing Non-Construction Investment}

Moving to the disaggregated analysis, the empirical investment model applied to annual 13-branches of manufacturing data for 1986-2012 has the following baseline specification: 22

$$
\begin{aligned}
\Delta i_{i, t}= & \alpha_{0}+\alpha_{1 i}+\alpha_{2 i} \Delta i_{i, t-1}+\alpha_{3 i} \Delta v a_{i, t}+\alpha_{4 i} \Delta \text { interest }_{i, t-1} \\
& +\alpha_{5 i} \text { liquidity }_{i, t-1}+\alpha_{6 i} \text { uncertaint }_{i, t-1}+\alpha_{7 i} \text { cycle }_{i, t-1}+\varepsilon_{i, t}
\end{aligned}
$$

All variables, except the interest rate and the dummy cycle variable, are expressed in logarithms, with $\Delta$ denoting first differences; coefficients may therefore be interpreted as elasticities. Branch-specific non-construction investment and value added are taken from Istat national accounts. Investment data were winsorised to eliminate possible outliers and to clean the dataset from idiosyncratic data points. ${ }^{23}$ The interest rate is the average bank lending rate to firms, the only series for which a sectorial breakdown is unavailable. Sectorial corporate liquidity conditions are proxied by the annual average of the percentage balances computed on the liquidity expectations of the manufacturing firms surveyed monthly by Istat. Demand uncertainty is proxied by a (branch-specific) dispersion measure of replies from the same survey regarding total order expectations,

\footnotetext{
Footnote 21 continued

expenditure is obtained) are not available at the time of writing: they are thus proxied by employing the dynamics of total public investment.

22 The 13 manufacturing branches we consider refer to Istat's subsections of the Ateco 2007 (national version of the Nace rev. 2 classification).

23 The winsorization is done by attributing to branch-year investment changes respectively below and above the 2.5 and 97.5 percentiles the values of these latter percentiles.
} 
as defined in the Sect. 4.1. The cycle variable is a dummy variable taking value 1 in expansionary years, capturing the general state of the Italian economy. ${ }^{24}$

The equation is estimated with the Arellano and Bond (1991) Generalized Method of moments (GMM) estimator for linear dynamic panel data. This estimator is validated since in all specifications the null hypothesis of no autocorrelation in first-differenced errors is not rejected at orders higher than one and the Sargan test on overidentifying restrictions is passed (i.e. the null that the restrictions are valid is not rejected). Given the relative long panel we deal with, we implement limits on the number of instruments in order not to weaken the latter test. ${ }^{25}$

Our results for the manufacturing sector are presented in Table 5, which offers three alternative specifications (with column $b$ as our baseline and preferred specification). Changes in lagged non-construction investment are negatively correlated with current changes in the same variable, suggesting irreversible investment decisions. Contemporary changes in output, which capture sector-specific demand conditions, positively affect non-construction investment expenditure, as expected. ${ }^{26}$ An increasing cost of lending dampens investment, as does decreasing corporate liquidity. Uncertainty is found to have a large significant negative impact on capital accumulation. Finally, favourable phases in the general economic cycle exert a positive, yet small, lagged, and weakly significant effect on sectorial capital spending.

An attempt was made also to test the effect, if any, of labour market regulation on investment dynamics in manufacturing branches, as suggested for example by Ciccarone and Saltari (2015). A measure of employment protection legislation (EPL) at the branch level is not available for Italy, so various proxies were attempted, although none were found to be statistically significant at the 10 per cent level, thereby leading to their exclusion from the baseline results reported in Table $5 .{ }^{27}$ We believe that either a more disaggregated analysis considering solely the intangible and innovative components of capital accumulation or a more comprehensive focus including also private service sectors are warranted in order to fully test the hypothesis put forth by

24 In particular, the dummy variable takes value 1 in all years within 1986-2012 except for 1992-1993, 1996, 2001-2002, 2008-2012. Time dummies introduced for each year were instead found to be insignificant.

25 Detailed test results are available upon request.

26 Lagged changes of over one year are instead not found to be significant. A similar result is obtained when replacing sectorial value added with industrial production.

27 In particular an attempted proxy was a sectorialised measure of employment protection legislation, obtained by interacting the corresponding OECD indicator for Italy, available at the total-economy level, with a sector-specific measure of "exposure" to regulation, following an approach first put forward by Rajan and Zingales (1998). Indeed, sectors which for technological reasons require a larger worker turnover are those which should be more intensely affected by changes in labour market legislation. Following recent empirical literature (e.g. Andrews and Cingano 2014), we construct a natural, non-regulation-induced, indicator of exposure to labour market regulation by taking branch-specific hiring rates in the US averaged over the period 1999-2007 from the U.S. Census Bureau. The U.S. is employed as a benchmark country in this respect, as its level of regulation is considered minimal relative to European countries. The sectorialised measure of labour market legislation thus obtained is however not statistically significant. A second proxy was a direct sectorial indicator of job turnover, computed from detailed Italian individual employee data in the 2009-2014 period, controlling for the type of contract and other individual characteristics of the labour relation (such as the reason for the contract termination). We again did not recover any significant effect. 
Table 5 Sectorial estimation results (dependent variable: non-construction investment change (t))

\begin{tabular}{|c|c|c|c|}
\hline & $a$ & $b$ & $c$ \\
\hline \multirow[t]{2}{*}{ Investment $(\mathrm{t}-1)$} & $-0.245^{* * *}$ & $-0.235 * * *$ & $-0.262 * * *$ \\
\hline & 0.000 & 0.000 & 0.000 \\
\hline \multirow[t]{2}{*}{ Value added (t) } & $0.316 * * *$ & $0.204 *$ & $0.215^{* *}$ \\
\hline & 0.004 & 0.056 & 0.034 \\
\hline \multirow[t]{2}{*}{ Lending rate $(\mathrm{t}-1)$} & $-0.036^{* * *}$ & $-0.025 * * *$ & $-0.029 * * *$ \\
\hline & 0.000 & 0.005 & 0.002 \\
\hline \multirow[t]{2}{*}{ Liquidity (level, t) } & & $0.285^{* * *}$ & $0.256^{* * *}$ \\
\hline & & 0.000 & 0.001 \\
\hline \multirow[t]{2}{*}{ Liquidity (level, t-1) } & $0.384 * * *$ & & $0.289^{* *}$ \\
\hline & 0.001 & & 0.042 \\
\hline \multirow[t]{2}{*}{ Economic cycle $(\mathrm{t}-1)$} & & $0.040^{*}$ & 0.020 \\
\hline & & 0.082 & 0.459 \\
\hline \multirow[t]{2}{*}{ Uncertainty $(\mathrm{t}-1)$} & $-0.327 * *$ & $-0.345 * * *$ & $-0.280 * * *$ \\
\hline & 0.000 & 0.001 & 0.001 \\
\hline \multirow[t]{2}{*}{ Arellano Bond test for $\mathrm{AR}(2)$} & -1.246 & 0.504 & -1.170 \\
\hline & 0.212 & 0.614 & 0.241 \\
\hline \multirow[t]{2}{*}{ Sargan test $(\chi)$} & 81.7 & 80.0 & 79.5 \\
\hline & 0.123 & 0.152 & 0.160 \\
\hline
\end{tabular}

Note: Arellano-Bond estimates on 312 observations, 13 groups; $(* * *)$ significant at $1 \%$ level, $(* *)$ significant at $5 \%$ level, $(*)$ significant at $10 \%$ level.

$p$ values in italics

Ciccarone and Saltari (2015) amongst others. This analysis however goes beyond the scope of this paper and we deem it to be an interesting avenue for future research.

Finally, limiting our estimation period to 1986-2007 leads to broadly similar results to those reported in Table 5, suggesting no significant break in the factors influencing the sectorial spending patterns during the recent recessionary years. ${ }^{28}$ Moreover, there appears no statistically significant difference in the correlations between exportoriented and domestic market-oriented branches. ${ }^{29}$

\section{Conclusions}

The decline in Italy's non-construction investment since 2007 has been of unprecedented severity, in both a historical and an international perspective. All investment goods were affected. In 2014 a large non-construction "investment gap" was registered in Italy, both relative to its pre-crisis peak and to its 2000-2007 average.

While sectorial investment rates fell across the board in 2008-2012, private nonfinancial services stand out as the main "culprit" of Italy's downturn, explaining two

\footnotetext{
28 It must be said, however, that investment data disaggregated by asset type and by manufacturing branch are only available until 2012, thereby losing out on another two recessionary years.

29 See the definition employed in Busetti et al. (2015).
} 
thirds of the decline in the aggregate propensity to invest. This negative contribution was compounded by that originating from the reallocation of value added from high investment intensity sectors (industry) to low investment intensity sectors (private non-financial services). Assuming this "between effect" will continue to be negative over the next years, significant positive investment growth should be undertaken in particular by private services in order to guarantee a sustained recovery and a closure of the afore-mentioned "investment gap".

Amongst the factors behind the recent non-construction investment slump, various results may be drawn out from our econometric analyses, broadly confirming indications arising from survey data. In addition to traditional determinants (demand conditions and the user cost of capital), uncertainty and credit supply conditions are found to have statistically and economically significant effects on firms' capital spending. According to our estimates, demand conditions were the main driver of the investment slump in the recent double recession. The user cost of capital provided a large negative impact during the most acute phases of the sovereign debt crises but since 2013 its contribution has reversed, owing to the expansionary monetary policy measures enacted. The constraints imposed by tight credit supply conditions were particularly large during 2009 and 2012. Uncertainty also provided a sizeable negative impact during the double recession; it appears as one of the main factors explaining the delay in the recovery of the Italian economy. The significance of these determinants and their impact on non-construction investment growth is confirmed by a specific panel analysis on the manufacturing branches, which cumulatively explain over a third of total non-construction investment. Again, uncertainty is found to have a significant negative impact on capital accumulation.

\section{Appendix: Recent Developments in Total and Non-Construction Invest- ment in the Four Largest Euro-Area Countries}

As well as in historical terms, Italy's investment slump was severe in an international comparison: total gross non-construction expenditure declined much more moderately in France and Germany, whereas the downturn in Spain was of a roughly comparable magnitude to Italy's (Fig. 8). Breaking down the components of tangible non-construction investment, developments in investment in information and communication technology were generally less unfavourable (in particular in France). ${ }^{30}$ Differently to Italy, intangible investment in all three other main euro-area countries had no significant setback during the two recent crisis episodes.

30 The full breakdown of tangible non-construction expenditure for Germany is not available, although investment in ICT and "other machinery, equipment and weapons system" cumulatively recorded more favourable trends than those of the documented transport equipment expenditure (here not shown). 

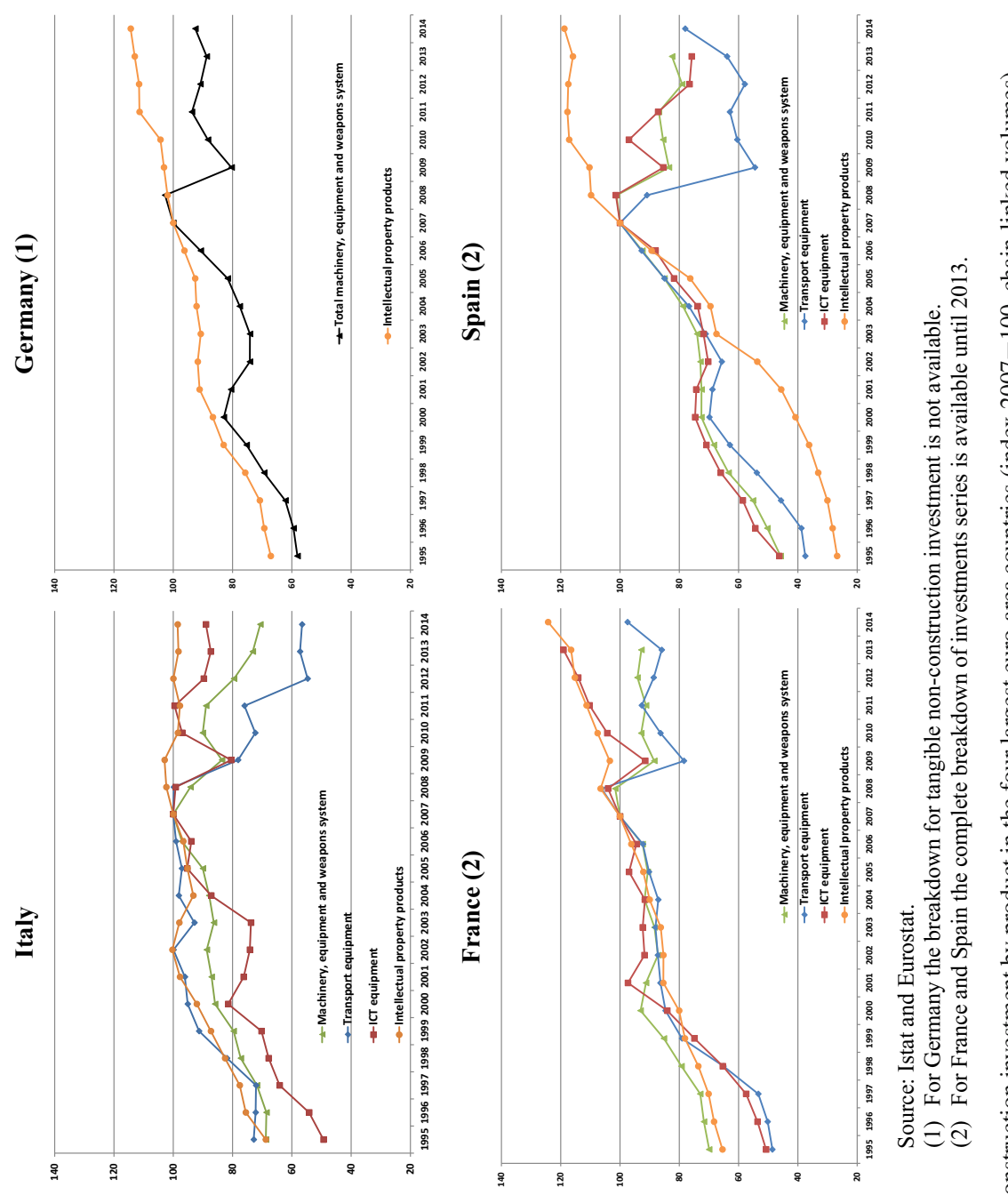


\section{References}

Abel A (1993) Optimal investment under uncertainty. Am Econ Rev 73:228-233

Andrews D, Cingano F (2014) Public policy and resource allocation: evidence from firms in OECD countries. Econ Policy 29(78):253-296

Arellano M, Bond S (1991) Some tests of specification for panel data: Monte Carlo evidence and an application to employment equations. Rev Econ Stud 58:277-297

Bachmann R, Elstner S, Sims ER (2014) Uncertainty and economic activity: evidence from business survey data. Am Econ J Macroecon 5(2):217-249

Banerjee R, Kearns J, Lombardi M (2015) (Why) Is investment weak? BIS Quarterly Review March

Barkbu B, Berkmen SP, Lukyantsau P, Saksonovs S, Schoelermann H (2015) Investment in the Euro area: why has it been weak? IMF Working Paper 15/32

Bernanke B (1983) Irreversibility, uncertainty, and cyclical investment. Q J Econ 98:85-106

Bloom N, Bond S, Van Reenen J (2007) Uncertainty and investment dynamics. Rev Econ Stud 74(2):391415

Bontempi ME, Golinelli R, Parigi G (2010) Why demand uncertainty curbs investment: evidence from a panel of Italian manufacturing firms. J Macroecon 32:218-238

Busetti F, Cova P (2013) L'impatto macroeconomico della crisi del debito sovrano: un' analisi controfattuale per l'economia italiana. Banca d'Italia Occasional Papers 201

Busetti F, Giordano C, Zevi G (2015) Main drivers of the recent decline in Italy's non-construction investment. Banca d'Italia Occasional Papers 276

Busetti F, Locarno A, Monteforte L (2005) The Bank of Italy's quarterly model. In: Fagan G, Morgan J (eds) Econometric models of the Euro-area central banks. Edwar Elgar, Cheltenham

Caballero RJ (1991) On the sign of investment-uncertainty relationships. Am Econ Rev 81:279-288

Caivano M, Rodano L, Siviero S (2010). The transmission of the global financial crisis to the Italian economy. A counterfactual analysis, 2008-2010. Banca d'Italia Occasional Papers 64

Carruth A, Dickerson A, Henley A (2000) What do we know about investment and uncertainty? J Econ Surv 14(2):119-149

Chirinko R (1993) Business fixed investment spending: modelling strategies, empirical results, and policy implications. J Econ Lit 31:1875-1911

Chirinko R, Schaller H (1995) Why does liquidity matter in investment equations. J Money Credit Bank 27(2):527-548

Ciccarone G, Saltari E (2015) Cyclical downturn or structural disease? The decline of the Italian economy in the last twenty years. J Mod Ital Stud 20(2):228-244

Eberly JC, Van Mieghem JA (1997) Multifactor dynamic investment under uncertainty. J Econ Theory 75:345-387

Fazzari S, Hubbard G, Peterson BC, Blinder AS, Poterba JM (1988) Financing constraints and corporate investment. Brook Pap Econ Act 1988(1):141-206

Fuss C, Vermeulen P (2008) Firms' investment decisions in response to demand and price uncertainty. Appl Econ 40(18):2337-2351

Gilchrist S, Sim JW Zakrajsek E (2014) Uncertainty, financial frictions, and investment dynamics. Federal Reserve Board, Finance and Economics Discussion Series 2014/69

Guiso L, Parigi G (1999) Investment and demand uncertainty. Q J Econ 114(1):185-227

International Monetary Fund (2015) WEO April

Leahy JV, Whited TM (1996) The effect of uncertainty on investment: some stylized facts. J Money Credit Bank 28(1):64-83

Panetta F, Signoretti FM (2010) Credit demand and supply in Italy during the financial crisis. Banca d'Italia Occasional Papers 63

Rajan RG, Zingales L (1998) Financial dependence and growth. Am Econ Rev 88(3):559-586

Saltari E, Travaglini G (2009) The productivity slowdown puzzle. Technological and non-technological shocks in the labor market. Int Econ J 23(4):483-509

Theil H (1952) On the time shape of economic micro-variables and the Munich business test. Rev Inst Int Stat 20:105-120 